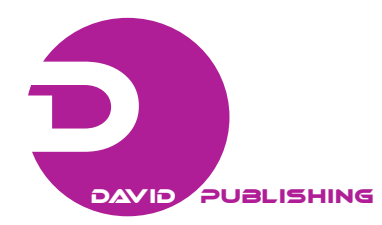

\title{
Electrochemical Immuno-Vascular Solid State Point of Care Testing (POCT)
}

\author{
Harold E. Braustein ${ }^{1}$, Klementiy Levkov ${ }^{1}$, Isabella E. Braustein ${ }^{2}$, Yifat Bezalel ${ }^{1}$, Majeda Abo Zaid ${ }^{1}$, Gideon \\ Fleminger ${ }^{1}$ and Judith Rishpon ${ }^{1}$ \\ 1. The George Wise Life Science Institute, Molecular Microbiology and Biotechnology Department, Tel Aviv University, Ramat-Aviv \\ 69978, Israel
}

2. Jerusalem District Health Office, Ministry of Health, Jerusalem 61999, Israel

Received: April 29, 2013 / Accepted: May 21, 2013 / Published: July 25, 2013.

\begin{abstract}
In this work, it is proposed a POCT and innovative method of immunoassay for the detection of C-reactive protein and $\mathrm{IgG}$, using Amperometry coupled to solid state kit, connected to a micro-flow system with comparable sensitivity to a high sensitivity CRP ELISA (hsCRP) and IgG ELISA, with 1-3 min turnaround time to result. Samples of CRP $\left(0\right.$ to $\left.250 \mathrm{ng} \cdot \mathrm{mL}^{-1}\right)$ and IgG or diluted spiked human serum are injected through a solid state polymeric kit, micro-flow sensor channels of a SWCT SPE nano-modified biosensor. Preparing two kits immuno-assays, in the same micro-column, built on oxirane groups of polymeric bead surface, with biological support to CRP and IgG biomarkers recognition, in a real time scheme, at the end of analyte injection the initial rate of change in current intensity I/A was proportional to CRP respectively IgG concentration, with low detection limit (LOD) of $0.1 \mathrm{ng} \cdot \mathrm{mL}^{-1}$. It was revealed that $\mathrm{CRP} / \mathrm{IgG}$ concentrations in serum that might be expected in both normal and pathological conditions can be detected in a real-time-efficient, multi-immunoassay with solid state detection kit technology with determined $\mathrm{CRP} / \mathrm{IgG}$ concentrations in close agreement with those determined using a commercially available high sensitivity ELISA.
\end{abstract}

Key words: Amperometrical, solid state POC kit, polymers, cardiovascular-immunological biosensor.

\section{Introduction}

Advances in the development of biochips, and microfluidic devices in particular, offer potential tender to monitor clinically relevant biomarkers in serum or other biological samples with economy in terms of sample volume, reagents and assay time. At the same time, these can be semi-automated for higher throughput applications, there is likely to be more impact in small devices for near patient and point of care applications $[1,2]$.

The amperometrical biosensors are known to be reliable, cheap and highly sensitive for the analysis of bioparameters present in food ingredients and

Corresponding author: Harold E. Braustein, full professor, research fields: electrochemical biosensors, diagnosis, heart diseases, infectious diseases. E-mail: harold.braustein@gmail.com. environment [3, 4]. The instrumentation system research have laid a good establishment for the growth of biosensors. The performance of the biosensor can be improved and studied in detail by using advanced instrumentation system [5]. The amperometrical biosensor will be preferred when there will be an appropriate interface between biosensing element and the related instrumentation system. Readout data is generated in real time, which can be analyzed to provide quantitative information including analyte concentration, analyte-receptor interaction specificities, affinities, and kinetics. In this paper, we connect the use of a polymeric micro-tip kit, containing the biological support (antibodies, enzymes) to a clinically relevant application, namely $\mathrm{CRP} / \mathrm{IgG}$ estimation. CRP is a classical acute phase reactant discovered by Tillett and Francis in the 1930's [6]. 
Although a fairly non-specific biomarker, the circulating concentration of $\mathrm{CRP} / \mathrm{IgG}$ rises Solid State Micro-Kit instantly (within minutes) in response to most forms of tissue damage, infection, and other acute inflammatory events including autoimmune diseases and malignancy, due the biological support linked to the beads (solid state). Since CRP/IgG can be elevated by as much as 1000 -fold over baseline $\left(\sim 100 \mu \mathrm{g} \cdot \mathrm{L}^{-1}\right.$ to as much as $\left.500 \mathrm{mg} \mathrm{L}{ }^{-1}\right)$, monitoring is considered very useful, not just for screening, but also for disease management since the level reflects not only the presence, but also intensity of inflammation or infection [7-9]. Further, CRP is stable with a long plasma half-life (about 19 h), remaining fairly constant with no diurnal or feeding induced variation [10]. In healthy blood donors, the median concentration is $0.8 \mu \mathrm{g} \cdot \mathrm{mL}^{-1}$, the 90 th percentile is $3 \mu \mathrm{g} \cdot \mathrm{mL}^{-1}$ and the 99th percentile is $10 \mu \mathrm{g} \cdot \mathrm{mL}^{-1}$ [11]. Routine commercially available assays for CRP quantification employ immunonephelometric and immunoturbidometric methods for CRP with ranges 3-8 $\mu \mathrm{g} \cdot \mathrm{mL}^{-1}$. SSID tests have been developed for point of care CRP applications, particularly with reference to management of bacterial infections [12]. These tests are however of relatively low-sensitivity with cut off values greater than $5 \mu \mathrm{g} \cdot \mathrm{mL}^{-1}$. Chronic inflammation is also an important component in the development of atherosclerosis.

A number of studies have demonstrated the utility of CRP as a sensitive biomarker of cardiovascular diseases, in particular, future coronary heart disease (CHD), independent of traditional risk factors [13]. Thus, the assessment of CRP levels could provide a predictive method to assess cardiovascular risk, or assess the potential risk of recurrent cardiovascular events [14]. The association between CRP and CHD is similar to that of traditional lipid risk factors [15-20]. A cut off level for CRP of 2-3 $\mu \mathrm{g} \cdot \mathrm{mL}^{-1}$ has been suggested [23]. The American Heart Association and the Centers for Disease Control and Prevention
(AHA/CDC) clinically assessed a number of inflammatory markers [16-19]. CRP had characteristics considered most useful for practice, although mass screening at this stage was considered unwarranted. Their guidelines suggest that CRP measurement be taken twice over a two week interval, less than $1 \mu \mathrm{g} \cdot \mathrm{L}^{-1} \mathrm{CRP}$ is "low cardiovascular risk", $1-3 \mu \mathrm{g} \cdot \mathrm{mL}^{-1}$ is "average” and greater than $3 \mu \mathrm{g} \cdot \mathrm{mL}^{-1}$ is "'high". Values greater than $10 \mu \mathrm{g} \cdot \mathrm{mL}^{-1}$ should be repeated with the patient being examined for sources of inflammation or infection.

Since this range includes levels in otherwise apparently healthy individuals, high-sensitivity CRP (hs-CRP) methods are required having limits of detection below that of routine assays (3 $\mu \mathrm{g} \cdot \mathrm{mL}^{-1}$ ). Automated immunonephelometric, immunoturbidometric methods now exist with assay ranges from as low as $50 \mathrm{ng} \cdot \mathrm{mL}^{-1}$ to $10 \mu \mathrm{g} \cdot \mathrm{mL}^{-1}$ and an immunoluminometric method has a range $100 \mathrm{ng} \cdot \mathrm{mL}^{-1}$ to $250 \mu \mathrm{g} \cdot \mathrm{mL}^{-1}$ for Ref. [21]. In addition commercial hs-CRP ELISA now exist with sensitivities as low as 1 to $5 \mathrm{ng} \cdot \mathrm{mL}^{-1}$ (American Diagnostica; Kalon Biological) but with a range to $100 \mathrm{ng} \cdot \mathrm{mL}^{-1}$. Clearly, such methods are either inefficient in terms of time or not easily transferable as POC (point of care) assays in a high sensitivity format, so there is potential for new high sensitivity, solid state immuno-amperometrical detection (SSID) methods [22]. Ideally, such a test might cover the dynamic range expected for both routine and high sensitivity assays. In addition, insights into the association of $\mathrm{CRP} / \operatorname{IgG}$ levels and other diseases are likely to require SSID assays of varying sensitivity or in novel matrices [23-26]. Herein we report our studies using electrochemical biosensor technology for $[\mathrm{CRP}] /[\mathrm{IgG}]$ quantification in diluted serum blood, in a micro-flow system.

\section{Materials and Methods}

\subsection{Materials}

All materials were obtained from Sigma-Aldrich 
Chemical Company (Rehovot, Israel) unless otherwise indicated.

\subsection{CRP/IgG-ELISA/Electrochemical Solid State} Assay Format

Human $\mathrm{CRP} / \mathrm{IgG}$ standards (range $0-10 \mathrm{mg} \cdot \mathrm{L}^{-1}$ ) were prepared by diluting a stock solution of $\mathrm{CRP} / \mathrm{IgG}$ $\left(24 \mathrm{mg} \cdot \mathrm{mL}^{-1}\right)$ in $50 \mathrm{mM}$ diethanol amine-hydrochloric acid (DEA-HCl), $25 \mathrm{mM}$ sodium chloride, $10 \mathrm{mM}$ calcium chloride, and $0.1 \%(\mathrm{v} / \mathrm{v})$ Tween 20, $\mathrm{pH}$ 6.0. PC-BSA-HRP (ALP-for IgG) conjugate $(1 / 8,000$ dilution) and specimens for analysis were also diluted in this buffer. Next, $50 \mu \mathrm{L}$ of standards or specimens and $50 \mu \mathrm{l}$ of the conjugate were added into micro wells (Optical Biosensor) previously coated with human CRP/IgG (100 ng/ well human CRP/IgG) (Fig. 1A). After incubation at room temperature for $30 \mathrm{~min}$, the micro wells are washed four times with $50 \mathrm{mM}$ DEA-HCl, $25 \mathrm{mM}$ sodium chloride, $10 \mathrm{mM}$ calcium chloride, $\quad 0.1 \% \quad(\mathrm{v} / \mathrm{v}) \quad$ Tween $20, \quad \mathrm{pH} \quad 7.4$. Tetramethylbenzidine $(2 \mathrm{mM} ; 100 \mu \mathrm{L})$ was added per well followed by a 15-min incubation (Fig. 1a). The reaction was stopped by adding $100 \mu \mathrm{L} 1 \mathrm{~N} \mathrm{H}_{2} \mathrm{SO}_{4}$ and the absorbance was read at $450 / 630 \mathrm{~nm}$ followed by calculation of specimen [CRP] from the standard curve. $0.1 \mathrm{mM}$ 1-naphtyl phosphate-substrate, was used for IgG-ALP labeled, for the amperometrical biosensor, $0.1 \mathrm{mM}$ 1-nitrophenyl phosphate-substrate, was used for IgG-ALP labeled, for the IgG Optical biosensor . This CRP-ELSA was validated with regard to assay parameters (time, temperature, buffer conditions), assay sensitivity and reproducibility, linearity of dilution, and multispecies CRP detection. Covalent coupling of PC-BSA to oxirane-modified microparticles Eupergit beads microspheres $(50 \mathrm{~m}$ diameter), were activated following addition of 0.1-15 $\mu \mathrm{g}$ a CRP/IgG/1 mg beads, $\mathrm{pH}$ 6.1. Following centrifugation $(10,000 \mathrm{~g}$ for $2 \mathrm{~min}, 3$ times $)$, microspheres beads were twice resuspended by sonication 3 times in $1 \mathrm{~mL} 50 \mathrm{mM}$ DEA-HCL, pH 6.1. Finally, the microspheres were resuspended by sonication in $1 \mathrm{~mL}$ of PC-BSA protein stock (1 $\left.\mathrm{mg} \cdot \mathrm{mL}^{-1}\right)$ in $100 \mathrm{mM}$ DEA-HCL, $\mathrm{pH} 8.5$, and mix at room temperature for $1 \mathrm{~h}$. Then, the microspheres were resuspended in $1 \mathrm{~mL}$ of $10 \mathrm{mg} \cdot \mathrm{mL}^{-1} \mathrm{BSA}$ in 100 mM DEA-HCl, $\mathrm{pH}$ 8.5. Finally, the microspheres ( $1 \%$ $(\mathrm{w} / \mathrm{v})$ suspension) were washed twice, resuspended in $1 \mathrm{~mL}$ of $50 \mathrm{mM}$ DEA-HCl, $25 \mathrm{mM}$ sodium chloride, $10 \mathrm{mM}$ calcium chloride, $\mathrm{pH} 7.4$, with sonication, and stored at $4{ }^{\circ} \mathrm{C}$ until required for use.

\section{Methods}

Screen printed electrodes (SPE) where bought from Gwent, U.K., Di-Ethanol Amine, bovine serum albumin (BSA), sodium chloride, Tween-20, Sheep IgG were from Sigma-Aldrich (Rechovot, Israel). Sheep anti-CRP, the hsCRP ELISA were from Kalon Biological (UK). hsELISA assay Spiked horse serum was tested for CRP content using a validated commercial hsELISA kit from Kalon Biological (Kalon Biological, U.K.). The assay was conducted according to the manufacturer's instructions, with spiked serum diluted to as low as 1 in 5 to as much as 1 in 10,000 in the supplied sample diluents.

\section{Instrumentation and Sensors}

SSID experiments were conducted using semi-automated micro-flow instruments (build in our laboratory by Dr. Klementiy Levkov). The instruments apply the principles of amperometrical technique, as a constant voltage is applied to a electrochemical cell (E.C., Fig. 1B-d) to measure the enzymatic reaction product, obtained by addition of a specific substrate to the micro-column tip (Fig. 1B-c), the current (obtained from electrons transfer, together with enzymatic reaction product, to the WE (working electrode) (Fig. 1B- $\mathrm{d}_{\mathrm{a}}$ ) of the SPE) is monitored in real time. The EC channel instruments comprise an "O"-ring (Fig. 1B- $\mathrm{d}_{\mathrm{b}}$ ) that seal the EC on a $10 \mu \mathrm{L}$ volume, mounted in micro-flow cells (Fig. 1B-d), allowing sample to be flowed across the WE surface. As sample is flowed across the biosensor, enzymatic 


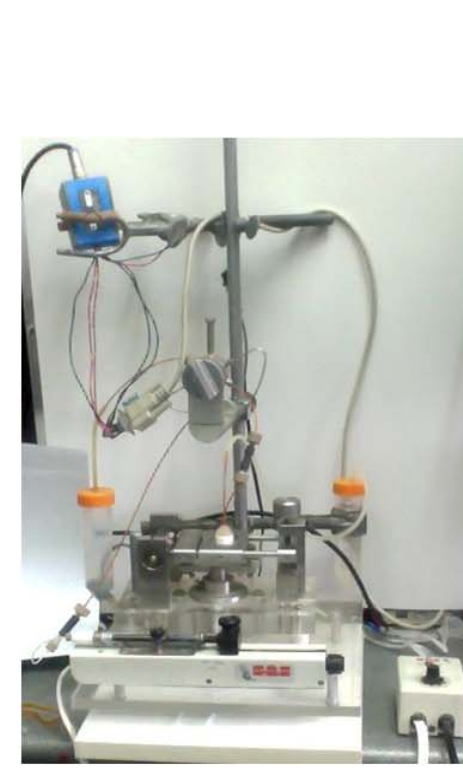

(A)

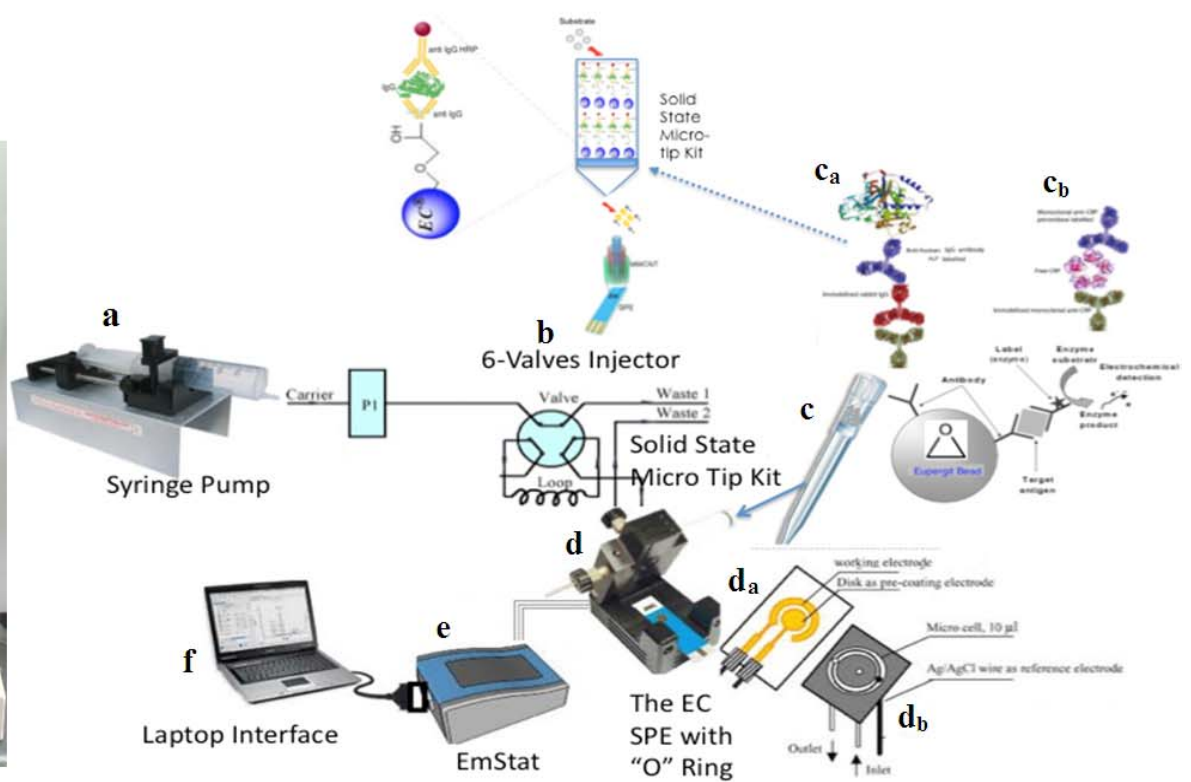

(B)

Fig. 1 (A) Picture of the micro flow system; (B) scheme of the flow chart of the IgG and CRP Solid State Kit multi arrays micro flow system and its components, (a) syringe pump (BeeSyringe, Bas, U.S.), with flow speed regulation; (b) 6 valves injector; (c) micro column tip kit; $\left(c_{a}\right)$ the IgG immuno sandwich built on the beads, $\left(c_{b}\right)$ the CRP immuno sandwich built on the beads, (d) the electrochemical cell; $\left(d_{a}\right)$ the screen printed electrode; ( $d_{b}$ ) the cell (“O”-Ring), building the $30 \mu \mathrm{L} \mathrm{EC.}$

product, if any, is measured as current.

For the electrochemical measurements are used 2 types of mini potentiostates: PalmStat and EmStat from PalmSense Inc., Netherland under software control of the same company. Micro fluidics comprised separate flow-paths to individual flow cells, based on capillary tubes, and combined with common high-pressure liquid chromatography (HPLC) connectors. Interchange between the different flow speeds and paths achieving the biological support (antibodies, antigens), the substrate, different buffers, was either by manual or Micro-Flow automatically-operated by Teflon connectors. Disposable Eupergit beads were packed into commercial plastic filtered microtips, within $2.5 \mathrm{mg}$, by weigh on a Sartorius Analytical balance. The beads are covalent linked to the biological support by their oxirane groups, with a carbon-oxygen-terminal layer coating to provide a surface for protein immobilization. Each kit contains two derivative sensors. The difference is possible by using specific antibodies for each biomarker (CRP and IgG) and two different enzymes (HRP and ALP) conjugated to the second antibody. In this manner, the substrate is reacted independently via a micro-fluidic system considered, for the specific assay. Using two disposable kits for one injection, the micro-flow cells (channel) can be used as a control for real-time measurements as required. The two micro column kits are docked by microcapilarry tubing into the micro-flow system instruments, allowing four simultaneous independent measurements to be carried out.

\section{Beads Surface Preparation}

The beads were prepared by immobilizing aCRP and aIgG onto the "active" oxirane groups through its carbon-oxygen oxirane group opening, with no further work up. Immobilization was performed at room temperature under continuous flow conditions with a running buffer, PBS, between sample injections was at a flow rate of $25 \mu \mathrm{L} \cdot \mathrm{min}^{-1}$. Each incubation-flow injection step taking $3 \mathrm{~min}$ at a very slow flow rate $\left(2.5 \mu \mathrm{L} \cdot \mathrm{min}^{-1}\right)$. The materials, Sheep $\alpha \mathrm{CRP}$ and $\alpha \mathrm{IgG}$ were prepared for immobilization at $0.1-15 \mu \mathrm{g} / \mathrm{mg}$ 
beads in $1 \mathrm{mmol} \cdot \mathrm{L}^{-1}$ diethanol amine-hydrochloric acid (DEA-HCl), $\mathrm{pH}$ 6.5, and were injected simultaneously through the Micro-Column Tip, Beads surfaces. Non-reacted surface was then capped with $0.1 \mathrm{M}$ DEA-HCl, $0.05 \%$ Tween-20 flowed at 250 $\mu 1 \cdot \min ^{-1}$, again in the same buffer. Finally, the surface of beads and microfluidic channels were blocked with $1.5 \%$ BSA (or Skim Milk) flowed at $2.5 \mu \mathrm{L} \cdot \mathrm{min}^{-1}$ BSA in DEA-HCl. The immobilization of the samples, calibrators, ezymes, was done in the same manner. The resulting Disposable Micro-Column Kits were stored at $4{ }^{\circ} \mathrm{C}$ until required.

\section{Serum and Blood Sample Preparation}

Normal human serum spiked with human CRP/IgG was supplied by Kalon Biological (UK). Spiked horse blood was prepared as follows. Spiked whole horse blood collected in EDTA tubes was kept refrigerated and used within $24 \mathrm{~h}$ of collection. The blood was centrifuged in $1.5 \mathrm{~mL}$ micro centrifuge tubes at $3,000 \mathrm{~g}$ for $5 \mathrm{~min}$ at $4{ }^{\circ} \mathrm{C}$, the upper layer was then aspirated. The whole blood volume was reconstituted by addition of the spiked serum appropriately diluted in normal serum to give blood spiked with human $\mathrm{CRP} / \mathrm{IgG}$ at $1.5 \mu \mathrm{g} / \mathrm{mL}$ (average $\mathrm{CRP} / \mathrm{IgG}$ ) and $15 \mu \mathrm{g} \cdot \mathrm{mL}^{-1}$.

\section{Standard Solid State Micro-Kit Assay for CRP}

All assays were performed at room temperature under continuous flow at $25 \mu \mathrm{L} \mathrm{min}{ }^{-1}$ with a running buffer of DEA-HCl pH $=9,0.005 \%$ Tween-20. $\mathrm{CRP} / \mathrm{IgG}$ standards were prepared in a sample buffer comprising DEA-HCl $\mathrm{pH}=9$ containing $0.005 \%$ Tween-20 and $100 \mu \mathrm{g} / \mathrm{mL}$ BSA from a concentrated stock solution (94.8 $\left.\mu \mathrm{g} \cdot \mathrm{mL}^{-1} \mathrm{CRP} / \mathrm{IgG}\right)$. CRP/IgG spiked serum was also appropriately diluted in the same sample buffer from a $1 / 50$ to $1 / 6,000$ dilution.

\section{Direct Detection Assay}

CRP/IgG DEA-HCl $\mathrm{pH}=9$ samples were prepared in sample buffer (DEA-HCl, 0.1\% BSA, $0.005 \%$
Tween-20). These were injected for 5 minutes, and the initial rate of association was monitored.

\section{Homogenous Sandwich Assay}

Sheep Anti-CRP/IgG antibody (Kalon Biological, UK) was added to CRP/IgG containing standards and samples prior to injection to give a concentration of $0.225 \mu \mathrm{g} \cdot \mathrm{mL}^{-1}$. The sample was then injected for $0.5 \mathrm{~min}$.

\section{Direct Sandwich Assay}

Following the direct capture step above, anti-CRP/IgG antibody was injected for $0.5 \mathrm{~min}$ at a concentration of $0.225 \mu \mathrm{g} \cdot \mathrm{mL}^{-1}$, and again the initial association was monitored. The surface was regenerated after each day of assay by using a pulse of $100 \mathrm{mM}$ Glycine- $\mathrm{HCl} \mathrm{pH} 2.5$ for $1 \mathrm{~min}$ and re-equilibrated in DEA-HCl $\mathrm{pH}=7$.

\section{Quantitative SSID Assay for CRP}

After gently mixing, spiked human blood samples were diluted 1 in 50 in sample diluents $\left(0.1 \mathrm{mg} \cdot \mathrm{mL}^{-1}\right.$ BSA in $10 \mathrm{mM}$ DEA- $\mathrm{HCl}, 150 \mathrm{mM} \mathrm{NaCl}, 3 \mathrm{mM}$ EDTA $\mathrm{pH}$ 7.4). The normalization standard was $27 \mathrm{ng} \cdot \mathrm{mL}^{-1} \mathrm{CRP} / \mathrm{IgG}$ in the same buffer (equivalent to $3 \mu \mathrm{g} \cdot \mathrm{mL}^{-1}$ serum in whole blood diluted 1/50). A standard assay was then performed with Sheep anti-CRP/IgG sensor surfaces as previously but using running buffer of $10 \mathrm{mM}$ DEA-HCl, $150 \mathrm{mM} \mathrm{NaCl}, 3$ mM EDTA pH 7.4. For each dual sensor channel chip, standard was passed over one disposable kit, spiked sample over the other. The blood preparation and $\mathrm{CRP} / \mathrm{IgG}$ screen was performed on three separate occasions. Blood samples were mixed by aspiration-dispense prior to loading onto sensor surface.

\section{Data Analysis Methods}

SSID data was analyzed as initial rates of signal generation (I/A) upon injection of $\mathrm{CRP} / \operatorname{IgG}$ or antibody onto a test channel containing immobilized anti-CRP/IgG. The data was displayed and analyzed 
using Palm Sense Inc. Software. Statistics were generated using Excel, and estimation of spiked samples was performed using a 4-parameter plot of the standards and appropriate dilution of the unknown spiked sera. For the quantitative assay, the initial rate of signal at the sandwich step was corrected for baseline slope and the ratio of blood sample signal to normalization standard signal was estimated.

\section{Results}

\subsection{CRP-ELSA Assay Format}

Human CRP/IgG standards (range $0-10 \mathrm{mg} \mathrm{L}^{-1}$ ) were prepared by diluting a stock solution of $\mathrm{CRP} / \mathrm{IgG}$ $\left(24 \mathrm{mg} \cdot \mathrm{mL}^{-1}\right)$ in $50 \mathrm{mM}$ DEA-HCl $25 \mathrm{mM}$ sodium chloride, $10 \mathrm{mM}$ calcium chloride, and $0.1 \%(\mathrm{v} / \mathrm{v})$ Tween 20, pH 6.0. PC-BSA-HRP conjugate (1/8000 dilution) and specimens for analysis were also diluted in this buffer. Next, $50 \mathrm{~mL}$ of standards or specimens and $50 \mathrm{~mL}$ of the conjugate were added into microwells previously coated with human CRP/IgG (100 ng/well human CRP) (Fig. 1A). After incubation at room temperature for $30 \mathrm{~min}$, the microwells are washed four times with $50 \mathrm{mM}$ DEA-HCl, $25 \mathrm{mM}$ sodium chloride, $10 \mathrm{mM}$ calcium chloride, $0.1 \%(\mathrm{v} / \mathrm{v})$ Tween 20, pH 7.4. Tetramethylbenzidine $(2 \mathrm{mM}$; $100 \mu \mathrm{L}$ ) was added per well followed by a 15 -min incubation. The reaction was stopped by adding 100 $\mu \mathrm{L} 1 \mathrm{~N} \mathrm{H}_{2} \mathrm{SO}_{4}$ and the absorbance was read at $450 / 630 \mathrm{~nm}$ followed by calculation of specimen $[\mathrm{CRP}] /[\mathrm{IgG}]$ from the standard curve. This CRP-ELSA was validated with regard to assay parameters (time, temperature, buffer conditions).

\subsection{SSID Assay Multi-arrays Design and Features}

The initial CRP assay carried out using SSID assay is designed around a two channel sensor "chip" disposable kits. Sheep $\alpha \mathrm{CRP} / \operatorname{IgG}$ was covalently coupled to the beads test channel using standard oxirane groups coupling chemistry. Sheep IgG coupled to the other channel demonstrated very low background signal in the appropriately diluted spiked serum samples. Sample and/or standards are passed over these channels in parallel to give a fairly SSID assay of 3 minutes maximum per cycle. $\mathrm{CRP} / \operatorname{IgG}$ is often monitored in autoimmune diseases where samples containing rheumatoid factor have very high incidence [27]. The sheep IgG channel can provide a suitable control for both this or anti-animal antibodies that are a potential interference in immunoassays [28, 29].

This initial CRP/IgG multi arrays assay carried out using SSID assay where compared with a commercial, validated high sensitivity ELISA by analyzing 6 spiked human serum samples across the range of AHA/CDC guidelines for CRP and immunological values for IgG. Good correlation for spiked serum samples above $5 \mu \mathrm{g} \cdot \mathrm{mL}^{-1}$ was found in all CRP assay formats using SSID (Fig. 2) when compared to commercial hsCRP ELISA (Table 1).

The trace shows typical data for the initial injection of a CRP containing sample (0-40 $\left.\mathrm{ng} \mathrm{mL}^{-1} \mathrm{CRP}\right)$. Signal is seen as association of the CRP onto the capture antibody (Direct Capture Assay). Next, human anti-CRP is injected to give a Direct Sandwich Assay. Again, an increase in signal is seen as association of current (I/A) function of [CRP] concentration (ng $\mathrm{mL}^{-1}$ ), Fig. $1 \mathrm{~A}_{1}$. The electrochemical direct sandwich assay also showed good correlation with ELISA(optical biosensor) this level $\left(\mathrm{R}^{2}=0.911\right.$; Fig. $\left.2 a_{2}\right)$. B. Real time analysis of [IgG] determination using Solid State Micro-Kit by sandwich immunoassay linked to Eupergit Beads. The trace show typical data for the initial injection of a $\operatorname{IgG}$ containing sample (0-140 $\left.\mathrm{ng} \mathrm{mL}^{-1} \mathrm{IgG}\right)$. Signal is seen as association of the IgG onto the capture antibody (Direct Capture Assay). Next, human anti-IgG is injected to give a Direct Sandwich Assay. As a result can be seen an increase in signal is seen as association of current (I/A) function of $\operatorname{IgG}$ concentration( $\mathrm{ng} / \mathrm{mL}$ ), Fig. $2 \mathrm{~B}_{1}$. The electrochemical direct sandwich assay also showed good correlation with ELISA (optical biosensor) this level $\left(R^{2}=0.934\right.$; Fig. $\left.2 \mathrm{~B}_{2}\right)$. The methods agree well, whilst the SSID method gave more sensitive values. 
(a)
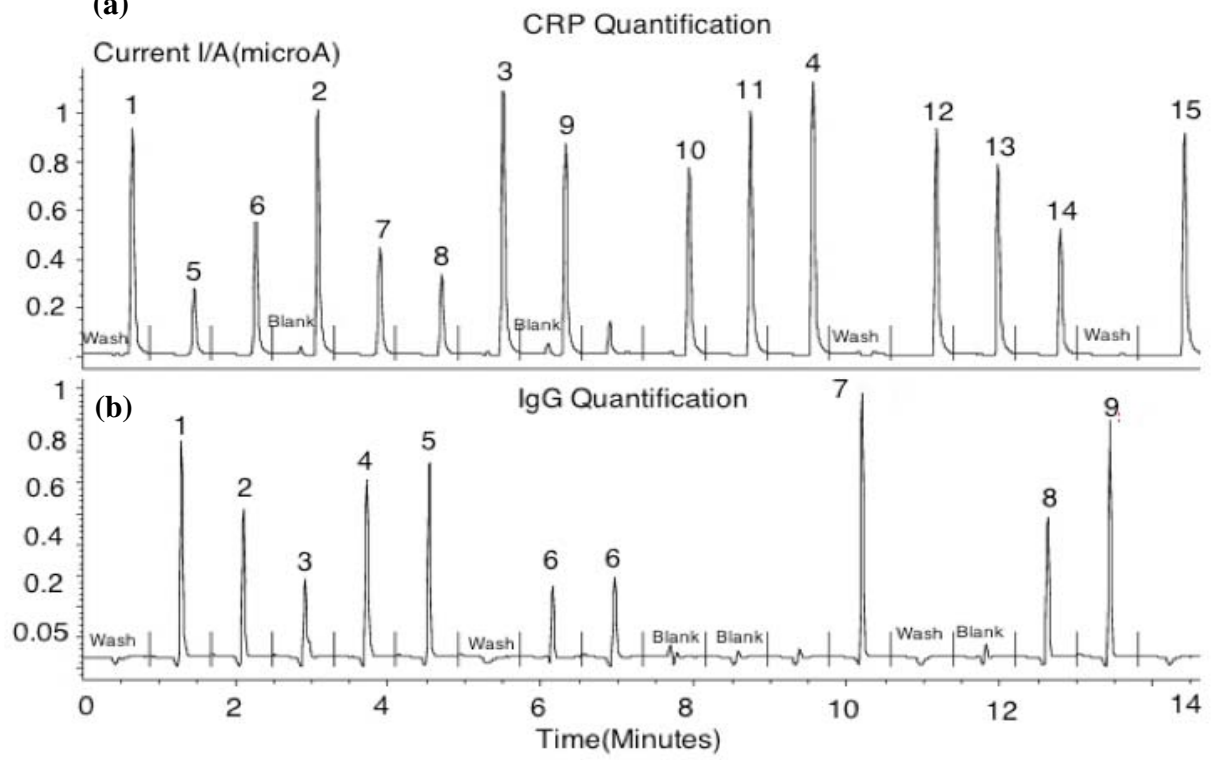

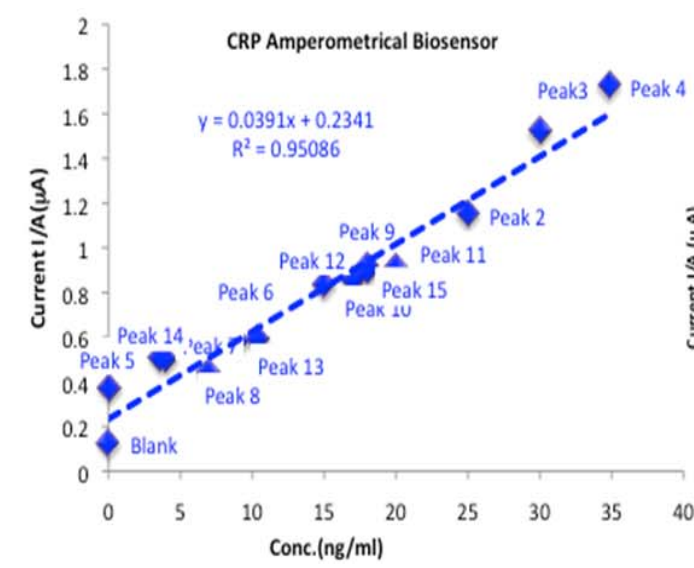

$\left(a_{1}\right)$

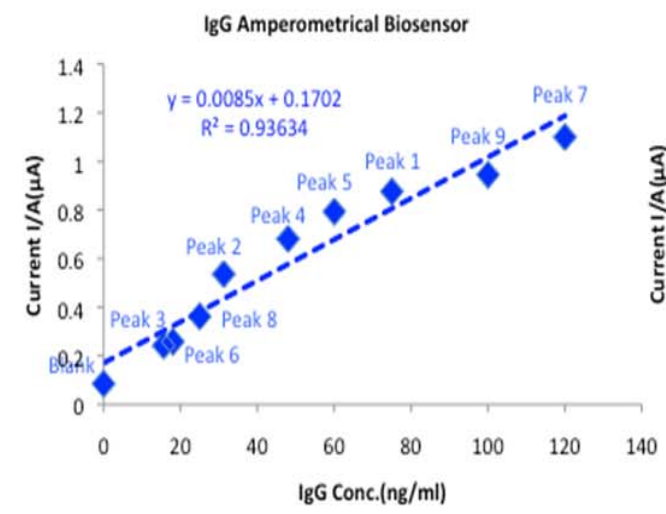

$\left(b_{1}\right)$

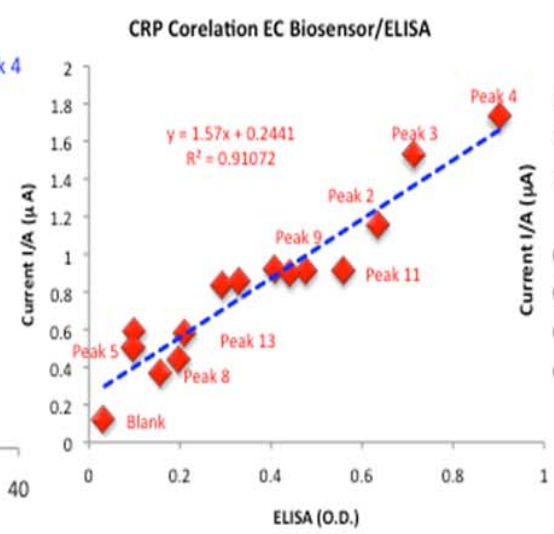

$\left(\mathrm{a}_{2}\right)$

IgG Corelation EC Biosensor/ELISA

CRP Corelation EC Biosensor/ELISA

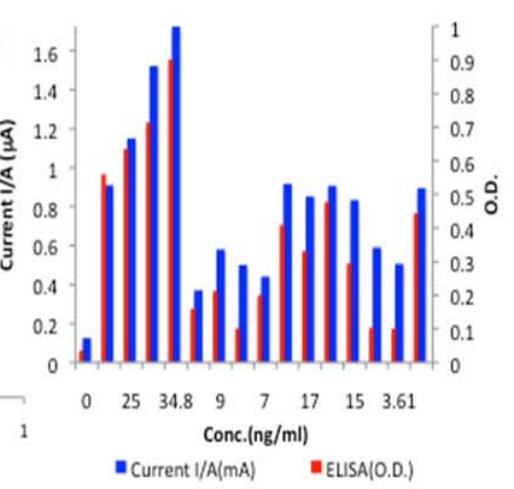

$\left(\mathrm{a}_{3}\right)$

IgG Corelation EC Biosensor/ELISA

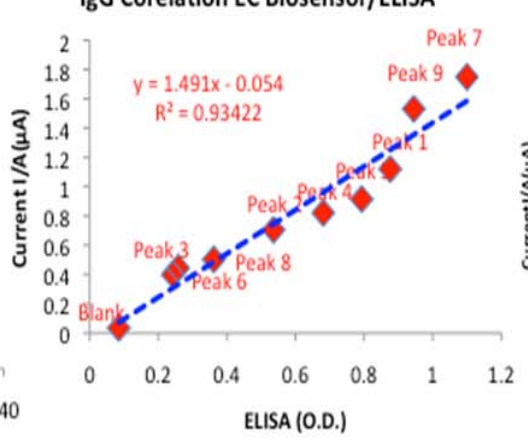

$\left(b_{2}\right)$

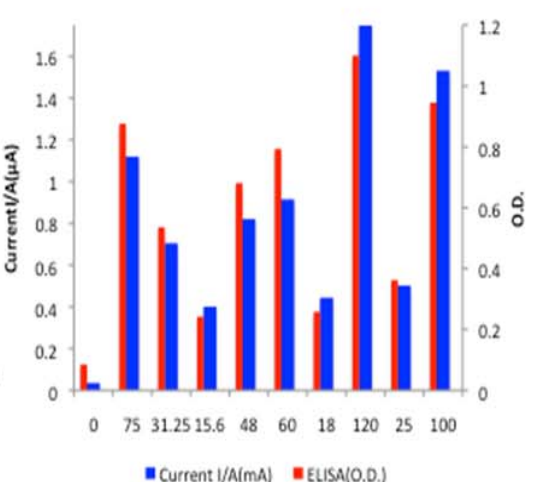

$\left(b_{3}\right)$

Fig. 2 Real time analysis of human serum [CRP]/[IgG] determination using SSMK in a sandwich immunoassay. (a) Results of CRP quantifications in the mini-flow system build; (b) results of IgG quantifications in the mini-flow system used; ( $a_{1}$ ) results for electrochemical immuno-assays of CRP amperometrical biosensor; $\left(a_{2}\right)$ and $\left(a_{3}\right)$ Correlation between results obtained using electrochemical and respective optical sensor for CRP quantifications; $\left(b_{1}\right)$ - Results for electrochemical immuno-assays of IgG amperometrical biosensor; $\left(b_{2}\right)$ and $\left(b_{3}\right)$ Correlation between results obtained using electrochemical and respective optical sensor for IgG quantifications, respectively. 
Table 1 Determination of serum CRP concentration using different SSMK assay formats.

\begin{tabular}{lllllll}
\hline \multicolumn{2}{l}{ Cardiovascular Risk (AHA/CDC guidelines)/[CRP] $(\mathrm{mg} / \mathrm{mL})$} \\
\hline Spiked serum [CRP] & Low $<1$ & Avg. 1 - 3 & High 3-5 & \multicolumn{1}{l}{ Very High > 10 } \\
hsCRP ELISA & 0.1 & 1.2 & 3.61 & 10.4 & 34.8 & 94.8 \\
Direct capture & 0.092 & 1.26 & 4.35 & 9.6 & 44 & 116 \\
Homogenous sandwich & 3.728 & 4.53 & 7.56 & 11.9 & 41 & 113 \\
Direct sandwich & 3.4 & 3.4 & 6.3 & 15.5 & 53 & 120 \\
\hline
\end{tabular}

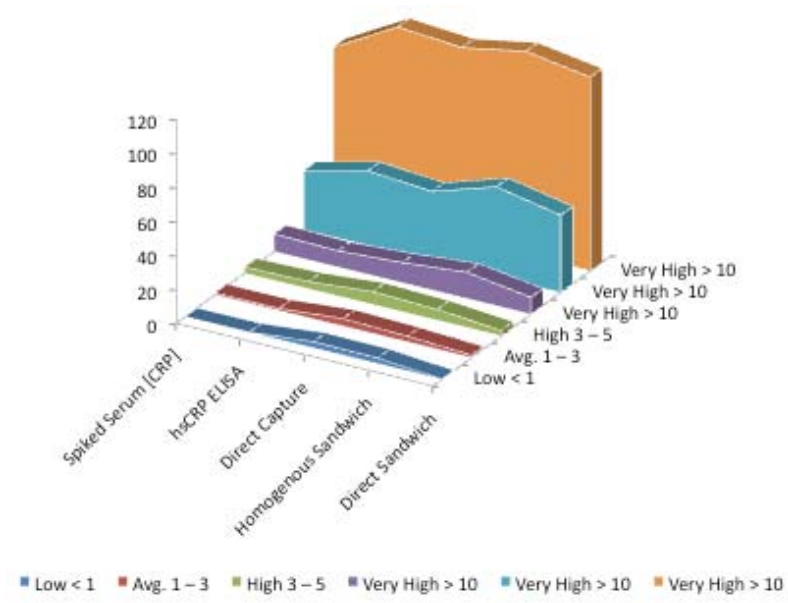

Fig. 3 Cardiovascular Risk (AHA/CDC guidelines)/CRP $\left(\mathrm{mg} \cdot \mathrm{mL}^{-1}\right)($ Graphic visualization of Table 1$)$.

The detection limit of the procedures was the amount of $\mathrm{CRP} / \mathrm{IgG}$ that could produce a signal in the test (anti-CRP channel) equivalent to the mean value of duplicate zero $\mathrm{mg} / \mathrm{L}$ CRP injections plus 3 times the standard deviation of the zero standard. For direct capture this was found to be $13 \mathrm{ng} \cdot \mathrm{mL}^{-1}$, for homogenous sandwich assay $20 \mathrm{ng} \cdot \mathrm{mL}^{-1}$ and for the direct Sandwich Assay $3 \mathrm{ng} \cdot \mathrm{mL}^{-1}$. Precision for the direct sandwich assay was determined using 3 test channels, injected with standard CRP concentrations from 0 to $232 \mathrm{ng} \cdot \mathrm{mL}^{-1}$ (Fig. 4). Below $10 \mathrm{ng} \cdot \mathrm{mL}^{-1}$ the coefficient of variation (CV) rose above $10 \%$, above this CRP concentration, a CV of $11.3 \%$ decreasing to $4.7 \%$ was observed.

An inter-assay, intra-assay precision profile analysis was performed by determining CRP/IgG concentrations of spiked serum samples using the sandwich assay in three to five replicates of each sample within test channels and different test channels (Table 1). The coefficient of variation (CV) lay between $3.1 \%$ to $12.6 \%$ across the range 0.1 to
$116 \mathrm{mg} \cdot \mathrm{L}^{-1}$ original concentration of spiked serum. Generally acceptable CV values in diagnostic methods are less than $10 \%$, the smaller the $\mathrm{CV}$ the more accurate the classification of sample. However, the level of imprecision found herein is similar to that of commercial hsELISA (e.g., IBL hsELISA, Hamburg, Germany quotes intra-assay CV of 5.5 and $6 \%$ for two samples of 22 and $99 \mu \mathrm{g} \mathrm{L}^{-1} \mathrm{CRP}$ and interassay variation of 11.6 and $13.8 \%$ for two samples of 22.1 and $90.4 \mu \mathrm{g} \cdot \mathrm{L}^{-1} \mathrm{CRP}$ ) and the results still indicate the assay is useful in differentiating the cardiovascular risk levels. In order to test the possibility of false negative results due to high CRP levels, the standard CRP range was extended approximately two fold higher $\left(231 \mathrm{ng} \cdot \mathrm{mL}^{-1}\right)$ than the hsELISA range. No hook effect was observed at this level (Fig. 4).

\subsection{Quantitative SSID Assay}

Whilst the standard CRP/IgG assay was able to provide quantitative results, calibration of a sensor channel response using standards prior to sample is a relatively "no time consuming" process. Since the turnaround time is $1 \mathrm{~min}$ per sample, then five singlet calibration standards prior to a sample would take one hour turnaround.

To deliver a more SSID quantitative assay from a blood sample, a simple, SSID ratio metric assay was thus performed. A normalization standard corresponding to a blood sample with $3 \mu \mathrm{g} \mathrm{mL}$ $\mathrm{CRP} / \mathrm{IgG}$ in serum was diluted 1 in 50 then passed over one channel. In parallel, a blood sample diluted 1 in 50 was passed over the other channel (Fig. 4). The chosen CRP normalization concentration 
corresponds to that of the 90th percentile and also the borderline between "average" and "high" AHA/CDC guidelines. If the signal ratio between the two channels is greater than 1 then a higher CRP/IgG level is present and thus "high" risk, if less than 1 , "low" risk and at 1 is borderline. Spiking of 3 separate blood samples at "average" $\left(1.5 \mu \mathrm{g} \cdot \mathrm{mL}^{-1}\right.$ CRP in serum or $0.68 \mu \mathrm{g} \cdot \mathrm{mL}^{-1}$ in whole blood) and 3

$[\operatorname{lgG}+$ CRP ] Quantification

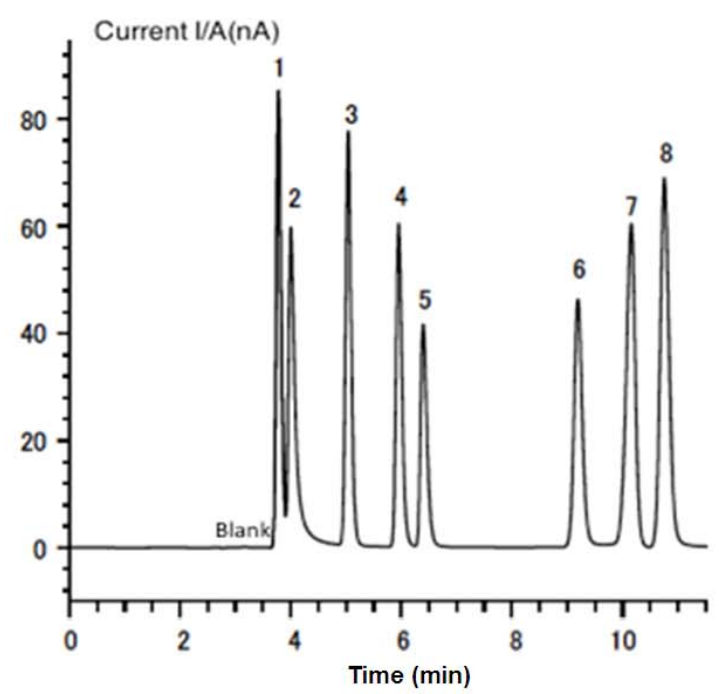

(a)

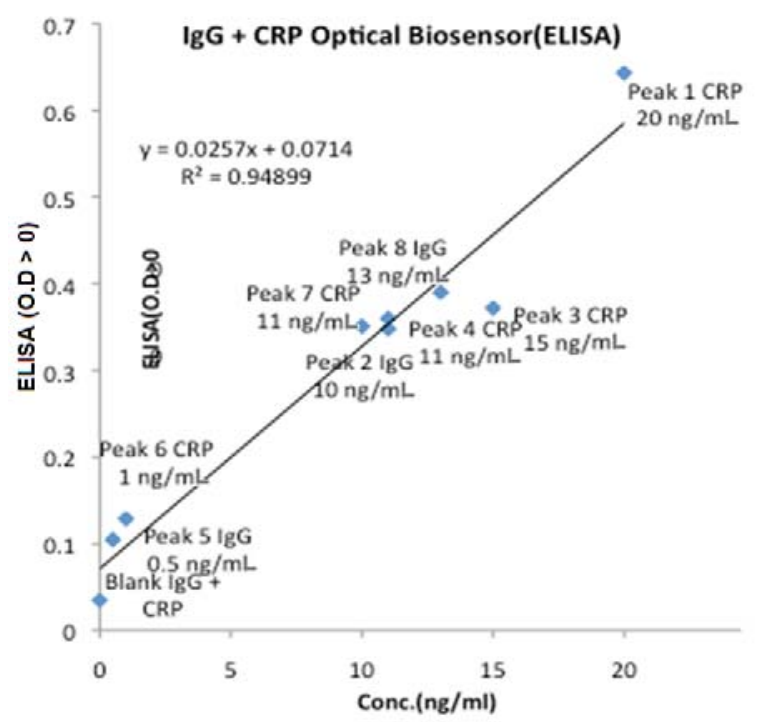

(c) separate blood samples at "high" $\left(15 \mu \mathrm{g} \cdot \mathrm{mL}^{-1}\right.$ in serum or $68.18 \mu \mathrm{g} \cdot \mathrm{mL}^{-1} \mathrm{CRP}$ in whole blood) CRP levels were tested. Ratios obtained gave excellent correlation with that expected for a calibrated sensor channel at these levels. For average CRP level blood the value obtained was $0.51+/-0.06$ (expected ratio $0.5, n=3$ ) and for high CRP level blood the value was $1.45+/-0.2$ (expected ratio $1.3, n=3$ ).

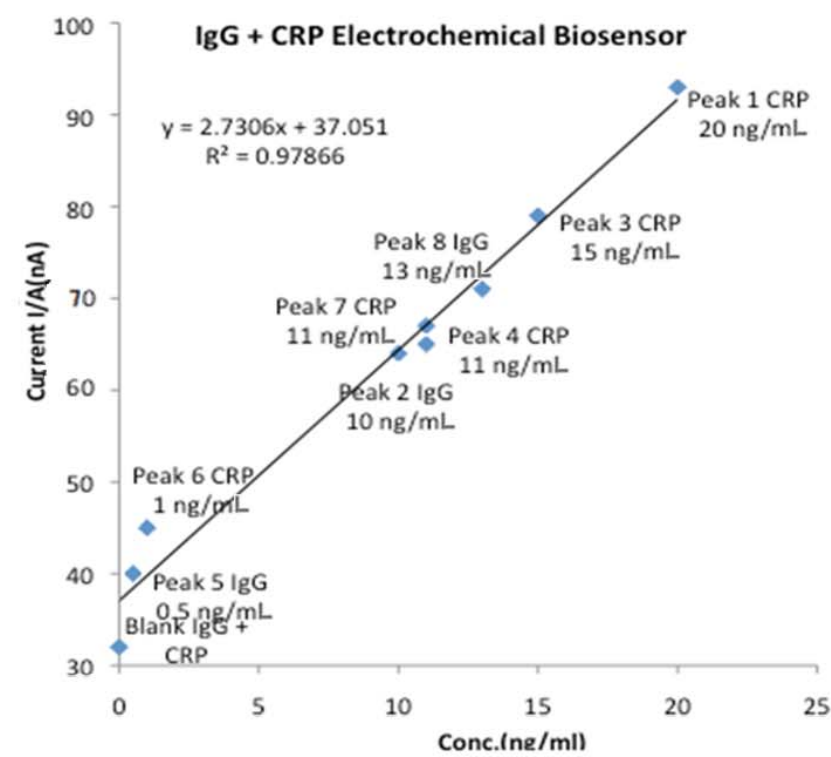

(b)

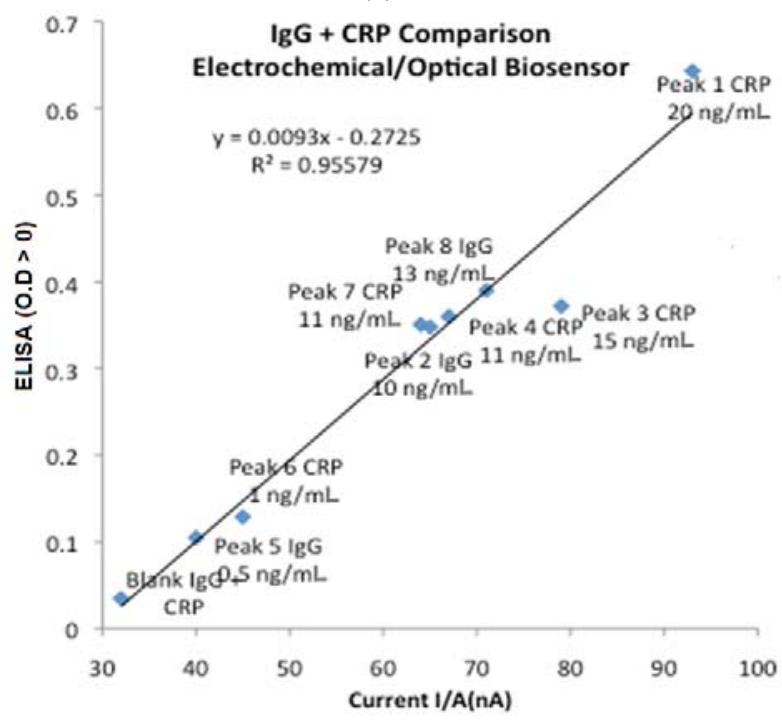

(d)

Fig. 3 Quantification of IgG and CRP using a solid state kit multi arrays micro flow system. (a) Flow chart of IgG and CRP quantification using a solid state kit on a multi arrays amperometrical analysis; (b) results obtained on the amperometrical immuno-multi assay of the electrochemical biosensor; (c) results obtained on the optical (ELISA) immuno-multi assay of CRP and IgG multi arrays sensor; (d) comparison between electrochemical biosensor and optical biosensor (ELISA) for CRP and IgG multi arrays quantification. 
Results are compared with that obtained by commercial hsCRP ELISA. Cardiovascular risk is considered at serum levels $>3 \mu \mathrm{g} \cdot \mathrm{mL}^{-1}$. Normal horse serum was independently spiked with human CRP, these samples were diluted from 1/100 to $1 / 6,000$ for assay. Sandwich assays using SSID employ $0.225 \mu \mathrm{g} \cdot \mathrm{mL}^{-1}$ Sheep a-CRP.

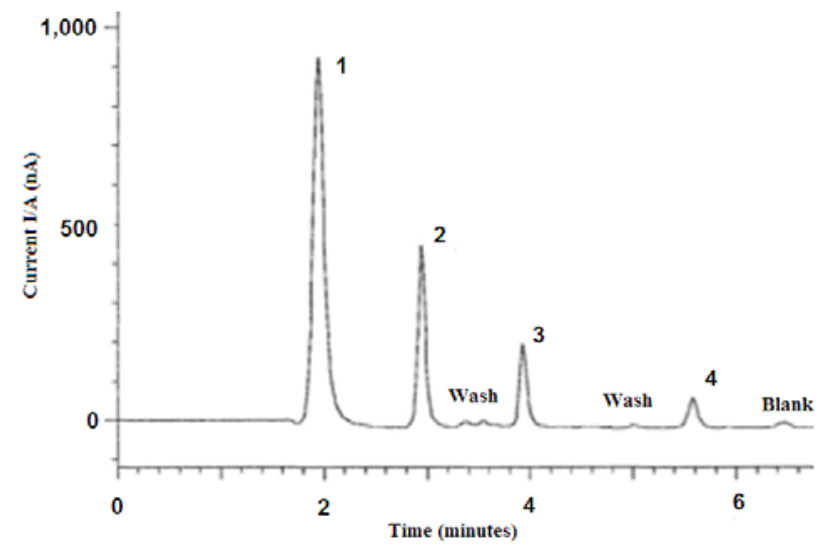

(a)

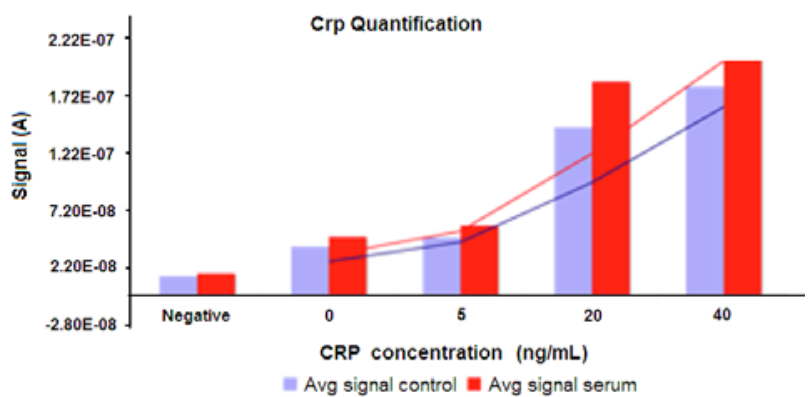

(c)
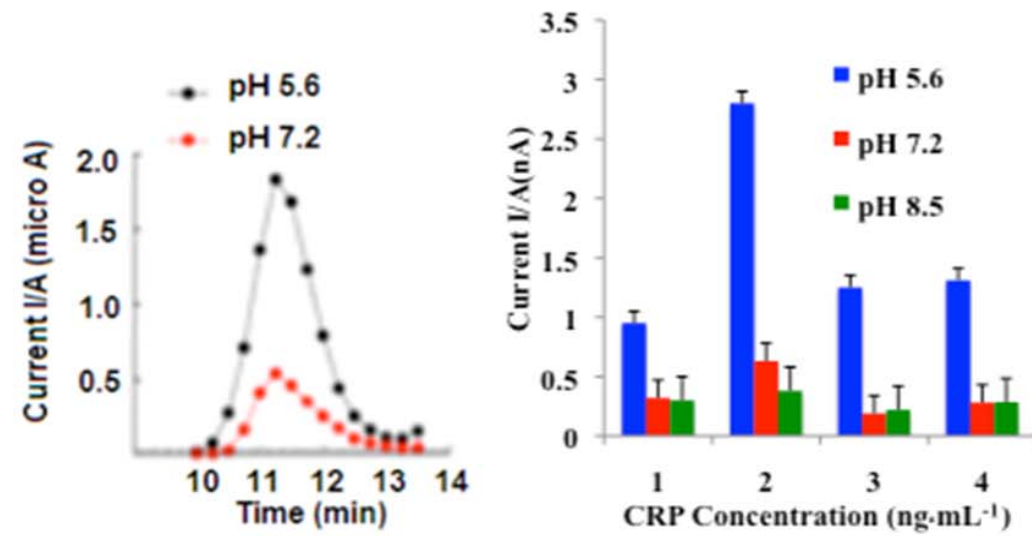

(e)

\section{Conclusions}

CRP and IgG measurement as an indicator of inflammation or infection status is widely used. Assays for routine analysis are sensitive enough to determine from $5 \mu \mathrm{g} \cdot \mathrm{mL}^{-1}$ upwards since this had been considered the upper limit in the normal range [28].

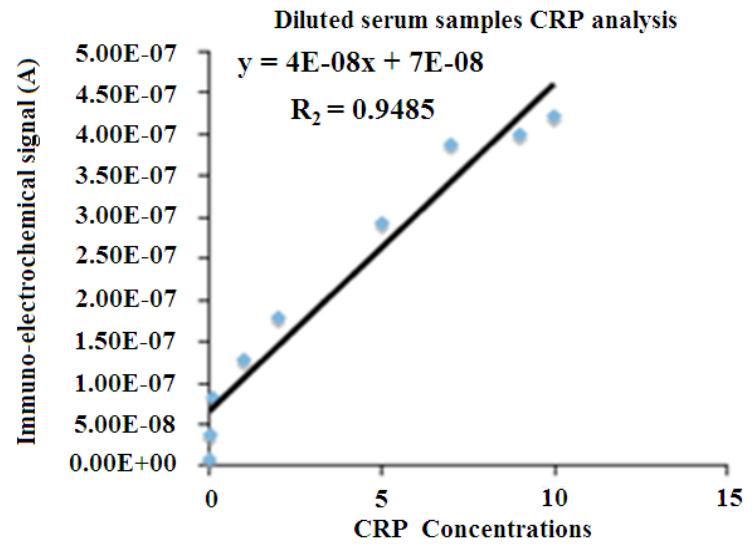

(b)

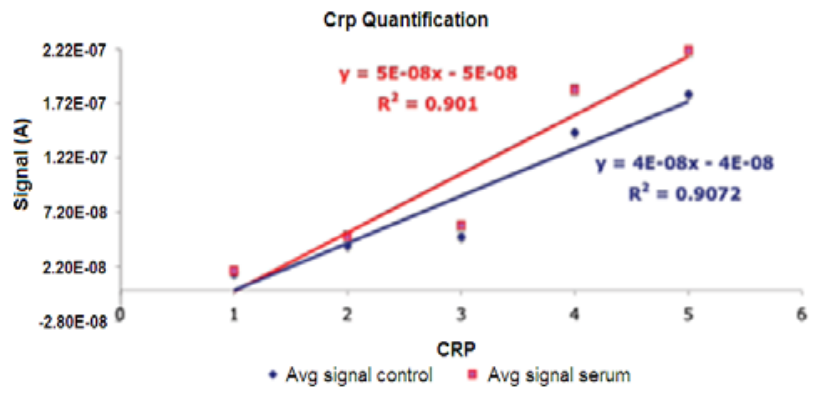

(d)

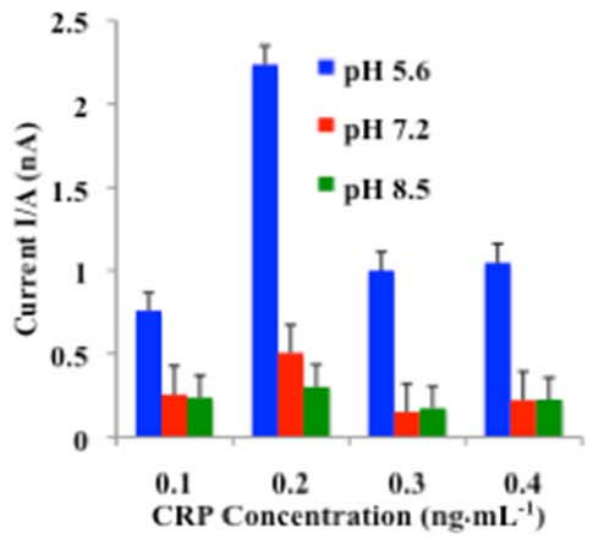

Fig. 4. (a) Flow chart of the optimization of the IgG and CRP solid state kit multi arrays micro flow system. (a) Immuno-response of CRP using the SSMK at different analyte(CRP) concentration; (b) immuno-electrochemical results for diluted CRP blood serum; (c) and (e) results obtained on the CRP amperometrical immuno-electrochemical multi assay of the human CRP spiked serum blood analysis; (d) Results of the working conditions optimization at different pH in the micro flow system. 
Point of care assays has been developed for this range and are best suited to monitor clearly pathological conditions. The utility of serum CRP/IgG levels as a predictive test for CHD is now well documented and various hsCRP assays have been developed to monitor $\mathrm{CRP} / \mathrm{IgG}$ patients with heart disease or a predisposition for heart disease. The principal advantages of the novel SSID described, in this paper, are the time, labor, and cost savings it offers, which overtakes the efficiency of the ELISA screening.

\section{Contending Interests}

Certain commercial entities, equipment or materials are identified in this paper to describe the new assay. This is not intended to imply recommendation nor that the entities, material or equipment is best suited for the purpose. Redundant publications: no substantial overlapping with previous papers.

\section{References}

[1] K.K. Jain, Applications of biochips: From diagnostics to personalized medicine, Curr. Opin. Drug. Discov. Devel. 7 (3) (2004) 285-289.

[2] T.H. Schulte, R.L. Bardell, B.H. Weigl, Microfluidic technologies in clinical diagnostics, Clin. Chim. Acta 321 (1-2) (2002) 1-10.

[3] D. Rawson, W. Gaisford, Biosensors monitor the environment, Control Instrum. 22 (1990) 63-64.

[4] U. Bilitewski, A. Jager, P. Ruger, W. Weise, Enzyme electrodes for the determination of carbohydrates in food, Sensors and Actuators B (1983) 113-118.

[5] H. Wohltjen, Chemical micro sensors and micro instrumentation, Anal. Chem. 56 (1984) 87-103.

[6] W.S. Tillett, T. Francis, Serological reactions in pneumonia with a non-protein somatic fraction of pneumococcus, J. Exp. Med. 52 (1930) 561-571.

[7] G.S. Wilson, D.R. Thevenot, Biosensors a practical approach, Oxford University Press, Oxford 1990, pp. 5-6.

[8] R. Wilson, A.P.F. Turner, Glucose oxidase an ideal enzyme, Biosensors and Bioelectronics 7 (1992) 165-185.

[9] V.G. Sangam, B.M. Patre, Development of computer based amperometric biosensor for the analysis of glucose concentration, in: Proc. International Conference, SICE-Japan, Okayama University, Japan, 2005, p. 105.
[10] S.D. de Ferranti, N. Rifai, C-reactive protein: A nontraditional serum marker of cardiovascular risk, Cardiovasc. Pathol. 16 (1) (2007) 14-21.

[11] W.S. Speidl, S. Graf, S. Hornykewycz, M. Nikfardjam, A. Niessner, G. Zorn, et al., High-sensitivity C-reactive protein in the prediction of coronary events in patients with premature coronary artery disease, Am. Heart J. 144 (3) (2002) 449-455.

[12] T.J. Wang, M.G. Larson, D. Levy, E.J. Benjamin, M.J. Kupka, W.J. Manning, et al., C-reactive protein is associated with subclinical epicardial coronary calcification in men and women, The Framingham Heart Study, Circulation 106 (10) (2002) 1189-1191.

[13] O. Gach, V. Legrand, Y. Biessaux, J.P. Chapelle, S. Vanbelle, L.A. Pierard, Long-term prognostic significance of high-sensitivity C-reactive protein before and after coronary angioplasty in patients with stable angina pectoris, Am. J. Cardiol. 99 (1) (2007) 31-35.

[14] P.M. Ridker, High-sensitivity C-reactive protein: Potentialadjunct for global risk assessment in the primary prevention of cardiovascular disease, Circulation 103 (13) (2001) 1813-1818.

[15] O. Bazzino, E.R. Ferreiros, R. Pizarro, G. Corrado, C-reactive protein and the stress tests for the risk stratification of patients recovering from unstable angina pectoris, Am. J. Cardiol. 87 (11) (2001) 1235-1239.

[16] P.M. Ridker, R.J. Glynn, C.H. Hennekens, C-reactive protein adds to the predictive value of total and HDL cholesterol in determining risk of first myocardial infarction, Circulation 97 (20) (1998) 2007-2011.

[17] P.M. Ridker, C.H. Hennekens, J.E. Buring, N. Rifai, C-reactive protein and other markers of inflammation in the prediction of cardiovascular disease in women, $\mathrm{N}$. Engl. J. Med. 342 (12) (2000) 836-843.

[18] F. Haverkate, S.G. Thompson, S.D. Pyke, J.R. Gallimore, M.B. Pepys, Production of C-reactive protein and risk of coronary events in stable and unstable angina, European Concerted Action on Thrombosis and Disabilities Angina Pectoris Study Group, Lancet. 349 (9050) (1997) 462-466.

[19] T.A. Pearson, G.A. Mensah, R.W. Alexander, J.L. Anderson, R.O. Cannon, M. Criqui, et al., Application to clinical and public health practice: A statement for healthcare professionals from the Centers for Disease Control and Prevention and the American Heart Association, Markers of Inflammation and Cardiovascular Disease, Circulation 107 (3) (2003) 499-511.

[20] W.L. Roberts, L. Moulton, T.C. Law, G. Farrow, M. Cooper-Anderson, J. Savory, et al., Evaluation of nine automated high-sensitivity C-reactive protein methods: Implications for clinical and epidemiological applications, 
Part 2, Clinical Chemistry 47 (3) (2001) 418-425.

[21] M.H. Meyer, M. Hartmann, M. Keusgen, SPR-based immunosensor for the CRP detection: A new method to detect a well known protein, Biosens Bioelectron 21 (10) (2006) 1987-1990.

[22] D. Mewar, A.G. Wilson, Autoantibodies in rheumatoid arthritis: A review, Biomedicine \& PharmacotheSolid State Micro-Kity 60 (10) (2006) 648-655.

[23] M. Andersson, J. Ronnmark, I. Arestrom, P.A. Nygren, N. Ahlborg, Inclusion of a non-immunoglobulin binding protein in two site ELISA for quantification of human serum proteins without interference by heterophilic serum antibodies, J. Immunol. Methods 283 (1-2) (2003) 225-234.

[24] L.J. Kricka, Human anti-animal antibody interferences in immunological assays, Clin. Chem. 45 (7) (1999) 942-956.

[25] A. Yu, U. Pira, False increase in serum C-reactive protein caused by monoclonal IgM-lambda: A case report, Clin. Chem. Lab. Med. 39 (10) (2001) 983-987.

[26] J. Winkles, J. Lunec, I. Deverill, Enhanced-latex-agglutination assay for C-reactive protein in serum, with use of a centrifugal analyzer, Clin. Chem. 33 (5) (1987) 685-689.

[27] F. Dati, G. Schumann, L. Thomas, F. Aguzzi, S. Baudner, J. Bienvenu, et al., Consensus of a group of professional societies and diagnostic companies on guidelines for interim reference ranges for 14 proteins in serum based on the standardization against the IFCC/BCR/CAP Reference Material (CRM 470), International Federation of Clinical Chemistry, Community Bureau of Reference of the Commission of the European Communities, College of American Pathologists, Eur. J. Clin. Chem. Clin. Biochem. 34 (6) (1996) 517-520.

[28] S. Eda, J. Kaufmann, M. Molwitz, E. Vorberg, A new method of measuring C-reactive protein, with a low limit of detection, suitable for risk assessment of coronary heart disease, Scand. J. Clin. Lab. Invest. Suppl. 230 (1999) 32-35.

[29] S. Eda, J. Kaufmann, W. Roos, S. Pohl, Development of a new microparticle-enhanced turbidimetric assay for C-reactive protein with superior features in analytical sensitivity and dynamic range, J. Clin. Lab. Anal. 12 (3) (1998) 137-144. 